[Vol. 126:696

\title{
IN RE HIGHWAY \& CITY FREIGHT DRIVERS LOCAL 600: AVAILABILITY OF BANKRUPTCY FOR LABOR UNIONS
}

\section{INTRODUCTION}

"[T]he growth and necessities of . . . labor organizations have brought affirmative legal recognition of their existence and usefulness and provisions for their protection ...." 1 Whether labor organizations should be afforded the protection of the Bankruptcy Act ${ }^{2}$ is currently under consideration by the Eighth . Circuit in the case of In re Highway \& City Freight Drivers Local 600.3. Specifically, two issues are presented for determination. The first is whether a labor union is a "person" entitled to the benefits of voluntary bankruptcy under section $4(a)$ of the Bankruptcy Act. ${ }^{4}$ The second issue (which assumes an affirmative response to the first) is whether a local union alone, or only in conjunction with its international, is the appropriate "person" for bankruptcy purposes.

Local 600 filed a voluntary petition in bankruptcy after judgments totalling about six million dollars were obtained against it in a suit under section 301 of the Labor Management Relations Act ${ }^{5}$ for breach of a no-strike clause in an existing collective bargaining agreement. ${ }^{\bullet}$ On the first issue presented, Bankruptcy Judge Brauer held that a labor union is an "association" within the meaning ascribed to that term by the Bankruptcy $\mathrm{Act}^{7}$ and, therefore, quali-

1 United Mine Workers v. Coronado Coal Co., 259 U.S. 344, 385-86 (1922).

2 Bankruptcy Act $\$ \S 1-755,11$ U.S.C. $\$ \$ 1-1255$ (1970).

3432 F. Supp. 1326 (E.D. Mo. 1977). The bankruptcy court's opinion notes that at least one other labor organization has filed a voluntary petition in bankruptcy. An order of discharge was entered in United Bhd. of Carpenters Local 930, No. 6-73-1062 (D. Minn. Oct. 6, 1975). The bankruptcy was not resisted by the local's creditors, and there was no reported decision entered in the case. In re Highway \& City Freight Drivers Local 600, No. 76-1517B, slip op. at 13 n.9 (E.D. Mo. Nov. 1, 1976), rev'd, 432 F. Supp. 1326 (E.D. Mo. 1977).

411 U.S.C. $\$ 22(\mathrm{a})(1970)$.

529 U.S.C. $\$ 185$ (1970).

6 The judgments were in favor of more than sixty motor carrier companies damaged by the union's strike. The International Brotherhood of Teamsters, Local 600 's affiliated parent organization, was not named as a defendant in the suit. Motor Carriers Council of St. Louis, Inc. v. Local 600, International Bhd. of Teamsters, 370 F. Supp. 461 (E.D. Mo. 1972), aff'd, 486 F.2d 650 (8th Cir. 1973) and 384 F. Supp. 214 (E.D. Mo. 1974), aff'd per curiam, 516 F.2d 316 (8th Cir. 1975).

711 U.S.C. $\S 1(8)(1970)$. 
fies as a "person" entitled to access to voluntary bankruptcy. ${ }^{8} \mathrm{He}$ found support for this conclusion in federal case law and legislation. ${ }^{9}$ Viewing both the policies of federal bankruptcy and labor law, the judge did not feel that the latter necessarily conflict with the former such that unions should be barred from the benefits of bankruptcy. In particular, he saw no cause to fear that unions would irresponsibly incur liability under labor law-for instance, through illegal strikes against employers-secure in the knowledge that bankruptcy would cushion them from the full financial consequences of their behavior. ${ }^{10}$

With regard to the second issue presented, the judge held that Local 600 was sufficiently autonomous to constitute an appropriate "person" for bankruptcy purposes, and, thus, that joinder of the international union was not necessary in order to entertain the section 4(a) petition. ${ }^{11}$ Although he recognized that the international had effective control over the local in many areas, he noted that the local had the power to manage its own finances, to own real and personal property, to hire employees and outside professional help, to make loans, and to settle local grievances. ${ }^{12}$ Calling the illegal strike on its own authority was cited as further evidence of local independence from the international. ${ }^{13}$ Weight was also accorded to the fact that the employers who were now complaining that the international must be joined to the bankruptcy proceedings had omitted to join the international as defendant along with Local 600 in the original section 301 controversy. ${ }^{14}$

On appeal the federal district court per Judge Wangelin reversed, holding that a labor union is not an "association" and, therefore, not a "person" entitled under section 4(a) to the benefits of voluntary bankruptcy. ${ }^{15}$ In reaching a conclusion contrary to

8 No. 76-1517B (E.D. Mo., Nov. 1, 1976), rev'd, 432 F. Supp. I326 (E.D. Mo. 1977). An alternative basis for holding unions to be "persons" for bankruptcy purposes is that they are "bodies having . . . powers and privileges of private corporations not possessed by individuals or partnerships." II U.S.C. \$ I (8) (1970). Apparently Judge Brauer did not feel the need to develop this alternative line of argument. No. 76-15I7B, slip op. at 3-4.

9 No. 76-1517B, slip op. at 4-10.

10 Id. 11-12.

11 Id. 12-13.

12 Id. 12.

13 Id.

14 Id.

15432 F. Supp. 1326 (E.D. Mo. 1977). The district court, like the bankruptcy court before it, did not address whether unions qualified as "persons" for bankruptcy purposes on the ground that they are "bodies having ... powers and privileges of private corporations not possessed by individuals or partnerships." See note 9 supra; notes 23-29 infra \& accompanying text. 
that of the bankruptcy court, Judge Wangelin examined the language of the Bankruptcy Act, its legislative history, and alleged conflicts between bankruptcy and labor policies. Having held unions to be excluded from bankruptcy coverage in the first instance, the district judge did not reach the second issue of whether a local union could petition in voluntary bankruptcy without joinder of its international. ${ }^{16}$

In the following section this Comment argues by a thorough and critical analysis of the statutory language, the legislative history, and the relevant policies of bankruptcy and labor law that unions should come within the coverage of the Bankruptcy Act, contrary to the district court's holding. Section III examines the second issue presented by In re Highway of City Freight Drivers Local 600, which received only brief treatment by the bankruptcy court: whether a local union unjoined by its international may constitute the appropriate "person" entitled to voluntary bankruptcy under section 4(a). In particular, the relevance of the international's vicarious liability on the local union's debts (if such can be proven) is discussed. The "piercing the veil" cases are shown to present a separate issue, and it is argued that even assuming the international to be vicariously liable on the section 301 judgment, Local 600 is an appropriate "person" who may be adjudicated bankrupt without the international's joinder.

\section{Coverage of Labor Unions Uṇder the Bankruptcy Act}

\section{A. Statutory Construction}

Section 4(a) of the Bankruptcy Act provides "any person" access to voluntary bankruptcy. It states in full: "Any person, except a municipal, railroad, insurance, or banking corporation or a building and loan association, shall be entitled to the benefits of this [Act] as a voluntary bankrupt." 17 Section 1(23) defines "persons" as including "corporations, except where otherwise specified, and officers, partnerships, and women." 18 For purposes here, therefore, three types of "persons" eligible for voluntary bankruptcy can be distinguished: individuals, corporations (other than the expressly

16432 F. Supp. at 1330.

1711 U.S.C. $\$ 22$ (a) (1970). Regarding the excluded corporations, see Sovern, Section 4 of the Bankruptcy Act: The Excluded Corporations, 42 MNN. L. Rev. 171 (1957).

1811 U.S.C. $\S 1(23)(1970)$. 
excluded corporations listed in section 4(a)), and partnerships. ${ }^{19}$ At first glance, it would seem that many otherwise legally recognizable "entities" are excluded from bankruptcy by this definition of "persons." One must look further, however, to the definition of "corporation" in section $1(8)$ :

"Corporation" shall include all bodies having any of the powers and privileges of private corporations not possessed by individuals or partnerships and shall include partnership associations organized under laws making the capital subscribed alone responsible for the debts of the association, joint-stock companies, unincorporated companies and associations, and any business conducted by a trustee or trustees wherein beneficial interest or ownership is evidenced by certificate or other written instrument. ${ }^{20}$

Numerous other legal entities besides partnerships and corporations (understood narrowly as entities organized under state incorporation laws) are, therefore, entitled as "persons" to voluntary bankruptcy under this broad definition of corporation:

The definition in $\$ 1(8)$ [is] "meant to enlarge the statutory meaning of 'corporation' beyond its ordinary meaning" and calls for "a broad, inclusive construction of the language used." The five comprehensive classes of bodies, groups and businesses enumerated in the clause cover practically the whole range of private activities and enterprises, except those carried on by individuals as such and partnerships other than the specified type. ${ }^{21}$

This Comment argues that unions are either "bodies having . . powers and privileges of private corporations not possessed

19 The special provisions of Bankruptcy Act $\$ 5,11$ U.S.C. $\$ 23$ (1970) are applicable to partnership bankruptcies. See generally IA CoLruER oN BANKRUPTCY II 5.01-.39 (14th ed. Supp. 1976). It should be noted that limited partnerships are expressly within $\$ 5$ coverage period.

2011 U.S.C. $\S 1(8)(1970)$.

211 Colluer on Bankruptcy $\{1.08$ at 62 (14th ed. Supp. 1974) (footnotes omitted). One argument made by the district court illustrates how far it misconceived the true character of the section 1(8) definition of "corporation," and how far it failed to appreciate the definition's expansiveness and the definition's interaction with sections $I(23)$ and $4(a)$ to open up, rather than limit, access to bankruptcy for miscellaneous legal "entities":

Also, section $1(8)$ of the Act is one of two sections [the other being section $1(23)$ ] that defines person. In those two sections more than ten entities are listed, none of which are "labor organizations". The maxim expressio unius est exclusio alteritus, while not controlling, certainly supports the inference that labor unions are not considered persons under the Bankruptcy Act.

432 F. Supp. at 1328 (footnotes omitted). 
by individuals or partnerships," or, alternatively, that they are "unincorporated . . . associations," and thus fit into the statutory definition of corporation.

Both the bankruptcy and the district courts overlooked the argument that unions as "bodies having . . . powers and privileges of private corporations not possessed by individuals or partnerships" are thereby "persons" entitled to the benefits of voluntary bankruptcy.22 Unions have several "corporate" powers and privileges; for instance, section 301(b) of the Labor Management Relations Act endows unions with the capacity to sue and be sued, as well as with limited liability. ${ }^{23}$ Various other entities with these "corporate" privileges have been determined to be within the Bankruptcy Act's coverage. ${ }^{24}$ Section $1(8)$ itself underscores the weight

22 See notes 9,16 supra \& accompanying text.

23 Any . . labor organization may sue or be sued as an entity and in behalf of the employees whom it represents in the courts of the United States. Any money judgment against a labor organization in a district court of the United States shall be enforceable only against the organization as an entity and against its assets, and shall not be enforceable against any individual member or his assets.

29 U.S.C. $\$ 185(b)(1970$ ).

The nature of the limited liability privilege conferred by $\$ 301$ (b) has been illumined by the courts. In Atkinson v. Sinclair Refining Co., 370 U.S. 238 (1962), the Supreme Court held that a union's officers and members were not liable for the damages assessed against the union for violation of a no-strike clause. The Court analyzed the language and policy of the Labor Management Relations Act and stated, "We have already said in another context that $\$ 301$ (b) at least evidences a congressional intention that the union as an entity, like a corporation, should in the absence of agreement be the sole source of recovery for injury inflicted by it." "” Id. 249 (footnotes omitted) (emphasis supplied). Every case since Atkinson attempting to hold individual members liable under $\$ 301$ has failed. Williams v. Pacific Maritime Ass'n, 421 F.2d 1287 (9th Cir. 1970); Navajo Freight Iines Inc. v. International Bhd. of Teamsters, 291 F. Supp. 908 (D. Colo. 1968); Hall v. Pacific Maritime Ass'n, 281 F. Supp. 54 (N.D. Cal. 1968); Gilmour v. Wood, Wire and Metal Lathers Local 74, 223 F. Supp. 236 (N.D. III. 1963). Section 301(b) has even been interpreted to mean that individual union members are not liable for breach of a no-strike clause where the union itself is not found liable. Sinclair Oil Corp. v. Oil Workers Int'l Union, 452 F.2d 49 (7th Cir. I971).

Another corporate privilege possessed by unions but not by individuals or partnerships is perpetual succession. Because the language of the statute is that "all bodies having any of the powers and privileges of private corporations not possessed by individuals or partnerships" (emphasis supplied) are "corporations" entitled to voluntary bankruptcy, possession of only one corporate privilege, e.g., perpetual succession, seemingly is enough, therefore, to qualify unions as "corporations." A fortiori, as argued in the text, possession of several significant corporate privileges brings them within the Bankruptcy Act's coverage.

For a general discussion of the distinguishing powers of private corporations, see W. Fletcher, Cyclopedia of the Law of Private Corporations $\$ 5$ (rev. perm. ed. 1974). stated:

24 The court in In re Carthage Lodge, 230 F. 694, 701 (N.D.N.Y. 1916)

The bankuuptcy law has prescribed what "bodies" or associations of persons shall be deemed a corporation within its meaning, and this law is para- 
to be given to the limited liability privilege as a determinant of corporate identity for bankruptcy purposes: "partnership associations organized under laws making the capital subscribed alone responsible for the debts of the association" are treated as "corporations" for bankruptcy purposes and are not subjected instead to the special partnership provisions of section 5 of the Act. ${ }^{25}$

Supreme Court dicta expressly recognized that unions possess many attributes of corporations. In United States $v$. White ${ }^{26}$ the Court held that an officer of a labor union could not invoke the constitutional privilege against self-incrimination while refusing to produce union records because the privilege is essentially personal and applies only to natural individuals, not to corporate-like entities such as labor unions. ${ }^{27}$ In comparing a labor union to a corporation, the Court stated:

Structurally and functionally, a labor union is an institution which involves more than the private or personal interests of its members. It represents organized, institutional activity as contrasted with wholly individual activity. . . . The union's existence in fact, and for some purposes in law, is as perpetual as that of any corporation, not being dependent upon the life of any member. It normally operates under its own constitution, rules and by-laws. . . The union engages in a multitude of business and other official concerted activities, none of which can be said to be the private undertakings of all the members. Duly elected union officers have no authority to do or sanction anything other than that which the union may lawfully do; nor have they authority to act for the

mount. That an association of a considerable number of men under a common name, with a constitution and bylaws, and with power to elect governing trustees, and recognized by the statutes of the state as a single body or "entity," and given power to own real and personal property and sue and be sued, and act by its trustees duly elected as a single body, is a body having some of the powers and privileges of private corporations not possessed by individuals or partnerships, cannot be doubted. Such a body is differentiated from a partnership.

As for the significance courts attach to limited liability, see Gallagher v. Hannigan, 5 F.2d 171, 175 (1st Cir. 1922), cert. denied, 269 U.S. 573 (1925) ("The words 'no direct individual liability for the company's debts' furnish the main reason for the conclusion that such associations, although for some purposes partnerships, ... are not to be dealt with as partnerships under the Bankruptcy Act.") See also Pope \& Cottle Co. v. Fairbanks Realty Trust, 124 F.2d 132, 135 (1st Cir. 1941); In re Order of Sparta, 242 F. 235 (3d Cir. 1917).

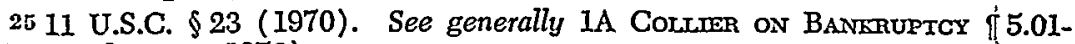

.39 (14th ed. Supp. 1976).

26322 U.S. 694 (1944).

27 Id. 699-700. 
members in matters affecting only the individual rights of such members. The union owns separate real and personal property .... ${ }^{28}$

The second argument in favor of Bankruptcy Act coverage for unions is that as "unincorporated . . . associations" they are included in the section $1(8)$ definition of "corporations" 29 and, therefore, are "persons" under the statute. This was the argument accepted by the bankruptcy court and rejected by the district court. ${ }^{30}$ The district court admitted "that the word association can normally be construed to include labor unions" but justified its rejection on the ground that "[s]ection $1(8)$. . . refers to business oriented entities with powers similar to corporations. A labor union is not generally considered such an entity." ${ }^{31}$ That unions possess many powers and privileges similar to those of corporations has already been discussed..$^{32}$ In any event, the district court emphasized that unions were not "business oriented," that they lacked "purposes like those of a monied business or corporation." 33 It noted that " $[\mathrm{u}] \mathrm{n}$ like a corporation a labor union does not pool capital for the purposes of investment and profit. Its assets are mainly its members who can collectively obtain bargaining leverage in labor-management negotiations. Its other financial functions are ancillary to this purpose." 34

The section $1(8)$ definition of corporation does not limit the entities that may be considered "corporations" to business oriented entities. The only pertinent reference in the Act to business orientation is in section 4 (b) which sets forth who may be an involuntary bankrupt. ${ }^{35}$ Section 4 (b) excludes "non-moneyed, business,

28 Id. 701-02 (footnote omitted).

29 Although it may seem odd to class an "unincorporated" association as a "corporation," this apparent contradiction in terms is explained by the broad inclusive purpose of the $\$ I(8)$ definition to reach miscellaneous legal "entities" by stretching "the statutory meaning of "corporation' beyond its ordinary meaning." See text accompanying note 22 supra.

30 See notes 9,16 supra \& accompanying text.

31432 F. Supp. at 1328 (emphasis supplied).

32 See notes 23-29 supra \& accompanying text.

33432 F. Supp. at 1328.

34 Id.

3511 U.S.C. $\$ 22(\mathrm{~b})$ (1970) states:

Any natural person, except a wage earner or farmer, and any moneyed, business, or commercial corporation, except a building and loan association, a municipal, railroad, insurance, or banking corporation, owing debts to the amount of $\$ 1,000$ or over, may be adjudged an involuntary bankrupt... and shall be subject to the provisions and entitled to the benefits of this title. 
or commercial corporation[s]" from involuntary bankruptcy, while section 4(a) (defining who may become a voluntary bankrupt) contains no such qualifying language. ${ }^{38}$ The exclusion of nonbusiness oriented entities from involuntary bankruptcy was intended to protect religious, educational and eleemosynary institutions; it was thought that they "should not have their laudible activities disrupted by liquidation at the instance of pestiferous creditors." ${ }^{37}$ It is perfectly consistent with this protective rationale to allow nonbusiness entities access to voluntary bankruptcy and its benefits. Indeed numerous cases have held eleemosynary and other nonprofit entities to be entitled to voluntary bankruptcy as "associations." 38

Judge Wangelin did not recognize the distinction between associations ("corporations") entitled to voluntary bankruptcy and associations which may not be subjected to involuntary bankruptcy. As support for the proposition that associations within the Act must be business oriented, Judge Wangelin cited Pope \& Cottle Co. $v$.

36 There are two classifications of bankrupts, voluntary and involuntary. A voluntary bankrupt has sought the protection of the bankruptcy court on its own volition. An involuntary bankrupt has been brought into court by its creditors.

The test for determining whether a "corporation" is subject to involuntary bankruptcy is whether the "corporation" is "moneyed, business or commercial." Bankruptcy Act $\$ 4(b), 1$ I U.S.C. $\$ 22(b)$ (1970). Because $\$ 4(b)$ has this qualifying phrase, which $\$ 4(\mathrm{a})$ (voluntary bankruptcy) does not contain, it is more difficult to show that an entity is within $\$ 4(b)$ than within $\$ 4(a)$. This Comment argues that a labor union is entitled to voluntary bankruptcy; however, labor unions may indeed possess many of the business characteristics required by $\S 4(\mathrm{~b})$. Supreme Court dicta in United Mine Workers v. Coronado Coal Co., 259 U.S. 344 (1922), indicate that a union is very much like a business: "[E]xtensive financial business is carried on, money is borrowed, notes are given to banks, and in every way the union acts as a business entity ...." Id. 385 . Further, the protective rationale, see text accompanying notes 37-38 infra, should not apply to labor unions because a union's activities, although they may be considered laudable, are not of the same nature as those performed by charitable, religious or educational institutions. That is to say, that a labor union's function is to benefit its members rather than society in general. Therefore, it could be argued that Congress did not intend to protect labor unions, and thus, unions should be subject to involuntary bankruptcy.

37 Sovern, supra note 18, at 232; see In re Michigan Sanitarium \& Benevolent Ass'n, 20 F. Supp. 979, 982 (E.D. Mich. 1937), appeal dismissed, 96 F.2d 1019 (6th Cir. 1938). For further discussion of this difference in the breadth of coverage between $\S 4(\mathrm{a})$ and $\S 4(\mathrm{~b})$, see In re Philadelphia Consistory, $40 \mathrm{~F}$. Supp. 645 (E.D. Pa. 1941).

38 E.g., In re Allen Univ., 497 F.2d 346, 348 (4th Cir. 1974) ("[A]n eleemosynary educational institution could be adjudged a bankrupt in a voluntary proceeding."); In re Michigan Sanitarium and Benevolent Ass'n, 20 F. Supp. 979 (E.D. Mich. 1937); In re Elmsford Country Club, 50 F.2d 238 (S.D.N.Y. 1931). Fraternal benefit societies have frequently been held eligible for voluntary bankruptcy. E.g., Grand Lodge, Knights of Pythias v. McKee, 95 F.2d 474 (5th Cir. 1938); Grand Lodge, Knights of Pythias v. O'Connor, 95 F.2d 477 (5th Cir. 1938); In re Philadelphia Consistory, 40 F. Supp. 645 (E.D. Pa. 1941); In re Grand Lodge, 232 F. 199 (N.D. Cal. 1916); In re Carthage Lodge, 230 F. 694 (N.D.N.Y. 1916). 
Fairbanks Realty Trust ${ }^{39}$ and Associated Cemetery Management, Inc. v. Barnes. ${ }^{40}$ The issue in both cases was whether, certain trusts were within bankruptcy coverage-Pope was an involuntary bankruptcy proceeding of a family trust and Associated Cemetery Management was a voluntary bankruptcy proceeding of an employee's profit-sharing trust. Neither trust was evidenced by certificates of beneficial interest. Lack of business orientation was in each case only an alternative ground for holding the trusts to be outside of the Act. The primary ground relied on in both was that because the section $1(8)$ definition of corporation expressly includes trusts "wherein . . . ownership is evidenced by certificate or other written instrument" ${ }^{41}$ (known as business or Massachusetts trusts), such express statutory provision for only a specific type of trust preempts implied inclusion of other kinds of trusts under the Act as "associations." 42

The secondary ground for the holding in Pope-that business orientation is necessary for an "association" to be entitled to bankruptcy is relevant to that case because Pope was an involuntary proceeding. It should not have been relevant to the Associated Cemetery Management case; nor should it be relevant to the disposition of the instant case because both cases involve voluntary bankruptcy proceedings. Thus, Judge Wangelin's construction of section $1(8)$ is erroneous and to the extent his holding relies on such it is necessarily incorrect.

\section{B. Legislative History}

The legislative history of those sections of the Bankruptcy Act setting forth the entities eligible for voluntary bankruptcy does not mention labor unions. Judge Wangelin addressed only the narrow issue of whether the union was an "association" within the Act. In

39124 F.2d 132 (1st Cir. 1941).

40268 F.2d 97 (8th Cir. 1959).

41 " 'Corporation' shall include . . . any. business conducted by a trustee or trustees wherein beneficial interest or ownership is evidenced by certificates or other written instrument." 11 U.S.C. $\$ 1(8)$ (1970). Regarding the addition of the proceeding language to the Act to extend coverage to Massachusetts trusts, see McLaughlin, Amendment of the Bankruptcy Act, 40 HaRv. L. Rev. 341, 355-65 (1927).

42 Congress, through use of this specific language, has singled out the Massachusetts trust as qualifying for bankruptcy proceedings, thereby indicating that trusts generally are not within the purview of the Bankruptcy Act. Absence of the required transferable certificates of interest is fatal to appellants' contention in this regard. 
so doing, he looked specifically at the legislative history of the Act of May 27, 1926,43 which amended the definition of corporation by adding the words "joint-stock companies, unincorporated companies and associations, and any business conducted by a trustee, or trustees, wherein beneficial interest or ownership is evidenced by certificate or other written instrument." 44 The House Judiciary Committee indicated that one purpose of the new language was to include within the definition of "corporation" certain trusts, ${ }^{45}$ in particular Massachusetts trusts. The report did not say, as Judge Wangelin suggested, ${ }^{46}$ that inclusion of these trusts within bankruptcy coverage was the only purpose of the amendment. ${ }^{47}$ Indeed, were that the only purpose, then the language, "unincorporated companies and associations," also added by Congress was superfluous.

The second aspect of the legislative history noted by Judge Wangelin was " $[t]$ he fact that the bankruptcy amendments of 1926 did not create . . a political debate." 48 This he contrasted to the "loud political controversy" that accompanied the proposal of legislation concerning labor organizations earlier in the century. ${ }^{49} \mathrm{He}$ concluded that the lack of ferment attendant to the 1926 bankruptcy amendments was "convincing evidence" that they could not have

43 Bankruptcy Act Amendment of 1926, Pub. L. No. 69-301, $\$ 1(6), 44$ Stat. 662 (1926).

44 Id. (emphasis supplied). For excellent background material on the 1926 Amendments, see Colin, An Analysis of the 1926 Amendments to the Bankruptcy Act, 26 CoL. L. REv. 789 (1926); McLaughlin, supra note 4 I.

45 The House Report concerning the 1926 amendment observed: "The object of this amendment is to include within the scope of the operation of the bankruptcy law, beyond any doubt, those businesses conducted under the guise of so-called trusts." H.R. REP. No. 877, 69th Cong., lst Sess. 6 (1926). In the House discussion Congressman Michener explained the proposed bill: "The meaning of the term 'corporations' is broadened so as to include common-law trusts, and so forth. Under the law today, common-law trusts, or what are sometimes called Massachusetts trusts, are not subject to the bankruptcy law, and this amendment cures this defect in the law." 67 CoNG. Rec. 7675 (1926) (emphasis supplied). It is clear that the amendment was designed to include at least Massachusetts business trusts; it is not clear why an amendment designed to add only these particular entities would be drafted with such broad language. Specifically there is the issue of what Congressman Michener meant when he said "and so forth". Thus the legislative history of the 1926 amendment is inconclusive of congressional intent to narrowly confine the extension of bankruptcy coverage effected by the new statutory language.

46432 F. Supp. at 1329.

47 Whether or not covered by the language added in 1926, there is the further possibility that labor organizations were already covered by the language of the original Bankruptcy Act of 1898 which included in the definition of corporation "all bodies having any of the powers and privileges of private corporations not possessed by individuals or partnerships." Bankruptcy Act of 1898, $\S 1$ (a) (6), 30 Stat. 544 (1898) (current version at 11 U.S.C. $\$ 1(8)$ (1970)). See text accompanying notes 23-29 supra.

48432 F. Supp. at 1329.

$49 \mathrm{Id}$. 
been intended to apply to unions..$^{50}$ The district judge's assertion notwithstanding, this inference of congressional intent to exclude unions from bankruptcy coverage is most assuredly not convincing. Four years prior to the bankruptcy amendments the Supreme Court held in United Mine Workers $v$. Coronado Coal Co. that unions were "associations" under the Sherman Act. ${ }^{51}$ Following the district court's logic, the convincing argument could be made that the word "association" was so clearly understood to include labor organizations after the Coronado Coal decision, that no congressional debate of the issue ensued. The only proper interpretation of the congressional silence evidenced in the legislative history with regard to bankruptcy coverage of unions is that it is inconclusive of congressional intent either to exclude or to include them.

\section{G. Bankruptcy and Labor Policies}

The construction of the statutory language and an examination of the legislative history affords little toward divining whether Congress intended unions to come within the Bankruptcy Act's coverage. This task is especially difficult because Congress has never specifically addressed the problem. Resolution of the issue ultimately must depend on the relevant policies of bankruptcy and labor law. The policy inquiry divides into two stages. The first stage of inquiry is whether inclusion or exclusion of unions is called for as a matter of bankruptcy policy. The second stage of inquiry, on the assumption that bankruptcy policy favors inclusion, is whether independent federal labor policies mandate exclusion of labor unions from bankruptcy coverage.

Two main policies underlie the Bankruptcy Act: providing debtors a fresh start through the discharge of their obligations and avoiding preferences among creditors through the equitable and expeditious distribution of the bankrupt's assets. ${ }^{52}$ The alternatives to federal bankruptcy are the state creditor remedies. Ordinarily the latter neither afford the debtor the relief of discharge nor prevent some creditors from achieving a preferred position vis-à-vis others by means of the debtor's cooperation or by being the first to exploit the most aggressive state collection procedure.53

$50 I d$.

51259 U.S. 344 (1922).

52 See, e.g., Louisville Joint Stock Land Bank v. Radford, 295 U.S. 555, 559, 587 (1935). Regarding the Act's provisions for discharge, see 1 I U.S.C. $\$ \$ 32-35$ (1970). Regarding its provisions for equitable adjustment and satisfaction of creditors' claims, see 11 U.S.C. $\$ \$ 91-112$ (1970 \& Supp. V 1975).

53 See J. Macluachlan, Law of BankRuptcy $\$ 5$ (1956). 
As Judge Wangelin conceded, ${ }^{54}$ inclusion of labor unions serves bankruptcy's twin purposes and avoids the inequities of state remedies. Furthermore, the rationale behind the express exclusion of certain entities from bankruptcy coverage does not justify an implied exclusion of unions. In the case of the excluded corporations, ${ }^{55}$ unlike other persons allowed the benefits of bankruptcy, Congress made the judgment that relegation to state remedies was appropriate.56 Because the excluded corporations for the most part were already subject to extensive state regulation, the view was that the bankruptcy policies would be substantially served by leaving state jurisdiction undisturbed in the case of these entities. ${ }^{57}$ Unions like Local 600 are subject to little, if any, specifically-designed state regulation; rather they are subject to the nearly exclusive regulation of federal labor law. ${ }^{58}$ Thus, it cannot be argued by analogy to the express exclusions, that an implied exclusion of unions is warranted because they are entities appropriately within the province of state regulation. To the contrary, the existing broad federal supervision of unions lends support to the view that federal supervision under the bankruptcy laws should be extended to insolvent unions. Alleged conflict between supervision of labor unions under the Bankruptcy Act and their supervision under federal labor-management statutes is a distinct ground that could justify excluding unions from bankruptcy coverage, and is treated next.

The goal of federal labor policy is to promote the rights of employees to organize and select representatives, to foster collective bargaining between employers and employees, and, ultimately, to favor the peaceful resolution of labor disputes. ${ }^{59}$ Bankruptcy policy

54432 F. Supp. at 1330.

55 The excluded corporations are "municipal, railroad, insurance, or banking corporation[s] .. . [and] building and loan association[s]." 11 U.S.C. $\$ 22(\mathrm{a})$ (1970). The municipal and railroad exclusions have lost much of their significance in light of special reorganization provisions now available. See 11 U.S.C. $\$ 205$ (1970).

56 Sovern, supra note 18 , at 172-82.

57 Id. It should be noted that Professor Sovern criticizes the exclusions and advocates that the excluded corporations be made the subjects of special federal bankruptcy provisions. Id. 207-43. Of course, merely because the rationale of the exclusions may be inapplicable to the excluded corporations themselves does not make it any less inapplicable to labor unions.

58 The text confines its analysis to unions within federal labor jurisdiction. Bankruptcy coverage of unions over which the National Labor Relations Board has not asserted jurisdiction, see 29 U.S.C. $\$ 164(\mathrm{c})(1)$ (1970), of public employee unions, see 29 U.S.C. \$152(2) (1970 \& Supp. V 1975), and of other such special unions may present different policy considerations, but discussion of these is beyond the scope of this Comment.

69 See Boys Markets, Inc. v. Retail Clerks, Local 770, 398 U.S. 235 (1970); Local 174, International Bhd. of Teamsters v. Lucas Flour Co., 369 U.S. 95, 104 
is consonant with this labor policy. Discharge of the section 301 judgment against Local 600 for the damages caused by its breach of its no-strike agreement with its employers will permit the union, the chosen agent of the employees, to continue to represent the employees in the administration of the collective bargaining agreement. Absent the availability to the union of discharge in bankruptcy, an employer who does not forgive the portion of the judgment debt not capable of satisfaction out of the union's existing assets could cripple the future functioning of the union by continually garnishing union member dues as they become payable to the union. ${ }^{60}$ Such a state of affairs is definitely not conducive to industrial peace. ${ }^{61}$ Indeed, in order to convince the employer to let loose its strangle-hold the union might resort to another illegal strike with further undesirable consequences for both parties. In two cases where employers have sought the benefits of discharge of executory collective bargaining obligations at the expense of employees, the Second Circuit resolved an apparent conflict of bankruptcy and labor policies by permitting the discharge of the employers. ${ }^{62}$

The employers in In re Fighway \& City Freight Drivers argued that if unions are given access to voluntary bankruptcy a labor

(1962); United Steelworkers v. American Mfg. Co., 363 U.S. 564 (1960); United Steelworkers v. Warrior \& Gulf Nav. Co., 363 U.S. 574, 578 (1960); United Steelworkers v. Enterprise Wheel \& Car Corp., 363 U.S. 593 (1960); Textile Workers Union v. Lincoln Mills, 353 U.S. 448, 454 (1957); 29 U.S.C. $\$ \S 102,141$, 151 (1970). See generálly R. Gorman, Labór Law 54 (1977); A. Cox, LAw AND the National Labor Poutcy (1960).

60 In In re Highway \& City Freight Drivers, the carriers who had obtained judgments against Local 600 garnished the union dues, remitting only a portion of the dues collected in the union check off. No. 76-1517B, slip op. at I n.1.

61 Dictum in Boys Markets v. Retail Clerks Local 770, 398 U.S. 235, 248 (1970) is appropriate: "[A]n action for damages prosecuted during or after a labor dispute would only tend to aggravate industrial strife and delay an early resolution of the difficulties between employer and union."

62 Brotherhood of Ry. Clerks v. REA Express, Inc., 523 F.2d 164 (2d Cir.);, cert. denied, 423 U.S. 1017 (1975); Shopmen's Local 455 v. Kevin Steel Prod., Inc., 519 F.2d 698 (2d Cir. 1975). The court observed in REA Express:

[T] the tension between the Bankruptcy Act's policy in favor of giving the debtor a new start and the Labor Act's policy of encouraging enforcement of collective bargaining agreements was resolved [in Kevin] by holding that, absent a clear Congressional mandate to the contrary... the enforcement of a collective bargaining agreement must yield to the bankruptcy court's power to relieve the debtor's successor in bankruptcy immediately of onerous and burdensome executory contracts.

523 F.2d at 167-68. The Second Circuit cases do not raise precisely the same issue as In re Highway \& City Freight Local 600. They involve Chapter XI bankruptcy reorganizations and the power of the reorganized employer-a new juridical entityto disaffirm an onerous and burdensome collective bargaining agreement negotiated with a union by the predecessor employer-entity. See Bankruptcy Act $\S 313(1)$, II U.S.C. $\$ 713$ (1) (1970). Nonetheless their approach to reconciling the policies of bankruptcy and labor law is informative. 
union would be able "to break its collective bargaining agreement(s) with impunity, comforted in the knowledge that a bankruptcy discharge would relieve it from the full consequences of the breach." ${ }^{83}$ There are several reasons to believe that labor unions would not act irresponsibly if voluntary bankruptcy is made available to them. As a bankrupt, a union must still face part of the adverse consequences of its behavior through the distribution of its assets. Bankruptcy Judge Brauer noted, "Experience has not demonstrated, generally, that the availability of bankruptcy relief has been an important, decisive factor in the course of conduct of one's ordinary human and business affairs with another." ${ }_{44}$ Furthermore, the Bankruptcy Act contains a safeguard that will deter bad faith breaches of the collective bargaining agreement. Section $14(c)(5)^{65}$ of the Act prohibits a bankruptcy court from discharging the debts of persons who have had a previous discharge in bankruptcy within the prior six years. A labor union could not, therefore, con: tinuously abuse the privileges of the Act.

\section{Appropriate Bankruptcy Person-the LOGAL OR THE INTERNATIONAL?}

The preceding section set forth the arguments in favor of bankruptcy coverage of labor organizations. Given union access to bankruptcy, the second issue presented by Highway of City Freight Drivers Local 600 is which structural division of a labor organization, $^{66}$ the local or the international, is the appropriate person entitled to petition for bankruptcy pursuant to section 4 (a) of the Act. Phrased differently, the issue presented is whether Local 600 is entitled to voluntary bankruptcy in its own right or whether it must be joined in its petition by its international.

As has been noted, ${ }^{67}$ only the bankruptcy court reached this second issue. In effect, Judge Brauer applied a facts and circumstances test of functional autonomy. Pointing to indicia of Local 600 's independence from international control of its operations and its property, he concluded that Local 600 was sufficiently autonomous to constitute a "person" separate from its international for

63 No. 76-1517B, slip op. at 11.

64 Id.; see Shopmen's Local 455 v. Kevin Steel Prod., Inc., 519 F.2d 698, 705-06 (2d Cir. 1975).

6511 U.S.C. $\oint 32$ (c)(5) (1970).

66 For discussions of the structure of a labor organization, see M. Forkosce, A Treatise on Labor Law, $\$ 110-22$ (2d ed. 1965); W. Leiserson, AMrerican Trade Union Dearocracy, 85-347 (1959).

67 See note 17 supra \& accompanying text. 
bankruptcy purposes. ${ }^{68}$ Another element given weight by the bankruptcy judge was the employers' failure to join the international as defendant in the original section 301 controversy. ${ }^{69} \mathrm{Hav}$ ing brought the latter suit against the local as an autonomous entity, the employers were in effect estopped from challenging the local's autonomy to go bankrupt on the judgment debt.

Of course the problem with a facts and circumstances test is the lack of predictability in any given case. Judge Brauer gave no precise indication of what quantum of independence from international control must be shown in a future case by a local union seeking adjudication as a bankrupt person. Importantly, his opinion is not inconsistent with the view that where employers can show sufficient control by the international as would make out a case against it of vicarious liability on the local's debts, then only the international is an appropriate bankruptcy person and the local's petition must be dismissed. The law is very confused on the issue of "piercing the veil" of an international and holding it vicariously liable on a local union's debts. ${ }^{70}$ In the interest of predictability, it is desirable, if possible, to avoid importing this confusion into the law on the availability of bankruptcy to appropriate persons.

The relevance of evidence of international control to the issue of whether a local union constitutes an appropriate bankruptcy person is tenuous at best. Although control evidence is obviously

68 No. $76-1517 \mathrm{~B}$, slip op. at 12-13.

69 Id. 12.

70 In deciding whether to "pierce the veil" of formal legal separateness and hold an international vicariously liable for damages resulting from its local's conduct, courts have applied general principles of agency law. See International Longshoremen's \& Warehousemen's Union v. Hawaiian Pineapple Co., Ltd., 226 F.2d 875, 880 (9th Cir. 1955); R. Gorman, supra note 59, at 218; Evans, The Law of Agency and the National Union, $49 \mathrm{Kx}$. L.J. 295 (1961). The courts are not in agreement as to what types and quantities of proof are necessary to establish the principal-agent relationship. Some courts have required proof of actual participation by the international in the conduct resulting in damage. E.g., Boeing Airplane Co. v. Aeronautical Indus. Dist. Lodge 751, 91 F. Supp. 596 (W.D. Wash. 1950), affd per curiam, 188 F.2d 356 (9th Cir. 1951); cf. Barefoot v. International Bhd. of Teamsters, 424 F.2d 1001 (10th Cir.), cert. denied, 400 U.S. 950 (1970) (international dismissed from suit for lack of venue, no principal-agent relationship having been shown). Other courts have inferred international participation on the basis of evidence of international control of the local contained in the international's constitution. E.g., Local 984, International Bhd. of Teamsters v. Humko Co., 287 F.2d 231 (6th Cir. 1961); cf. International Bhd. of Teamsters v. United States, 275 F.2d 610 (4th Cir. 1960) (if secretary-treasurer of local also an "agent" of the international then service of injunctive order on the secretary-treasurer constitutes valid service upon the international). One court has found the fact of local union members "furthering the organizational efforts and interests of the International Union" probative of an agency relationship. United Mine Workers v. Osborne Mining Co., 279 F.2d 716, 725 (6th Cir. 1960). 
relevant to the issue of an international's vicarious liability on the local's debts, that issue is a separate one which should not concern a bankruptcy court in its adjudication of the local's petition in bankruptcy. The crucial point is that the discharge afforded by bankruptcy extends only to the party adjudicated bankrupt. ${ }^{71}$ Thus, releasing Local 600 from future personal liability on its judgment debt to the employers to the extent such debt remains unsatisfied after the distribution in bankruptcy of the local's existing assets leaves unaffected any separate liability of the international on the debt. If the employers can prove the vicarious liability of the international on the section 301 judgment debt of the local, they are free to do so in another proceeding. ${ }^{72}$ Rebutting the international's vicarious liability should not be imposed as a condition to entertaining Local 600's petition in voluntary bankruptcy.

Of course, the employers may face a statute of limitations obstacle to an action against the international at this stage. Again, however, this does not present a bankruptcy concern. Indeed, any statute of limitations problem could easily have been avoided if the employers had originally joined the international as defendant under a vicarious liability theory in the section 301 suit against Local 600. There is no justification as a matter of bankruptcy policy for denial of the local's petition, absent joinder of the international therein, merely to allow the employers to recoup at Local 600 's expense their tactical error in failing to join the international in the original litigation. Similar considerations probably explain

71 Section 1(15) defines "[d]ischarge" as "the release of a bankrupt from all of his debts which are provable in bankruptcy, except such as are excepted by this [Act]." 11 U.S.C. $\$ 1(15)$ (1970). As a "corporation" a local union would have to apply for discharge within six months after its adjudication as bankrupt. 11 U.S.C. $\$ 32(a)(1970)$. Absent a showing of one of the reasons justifying denial of discharge of a dischargeable debt, see II U.S.C. $\$ \$ 32(\mathrm{c}), 35(\mathrm{a})$ (1970), an order of discharge would issue enjoining "all creditors whose debts are discharged from thereafter instituting or continuing any action or employing any process to collect such debts as personal liabilities of the bankrupt." II U.S.C. $\$ 32(\mathrm{f})(2)$ (1970) (emphasis supplied).

The section 301 judgment against Local 600 is dischargeable and does not fall into one of the Act's exceptions. See 11 U.S.C. $\$ 35(\mathrm{a})$ (1970).

72 Another possibility is that the trustee in bankruptcy could sue on behalf of the employers against the international on its primary liability and then distribute the proceeds of any judgment thereby obtained as a part of the local's estate in satisfaction of its debt to the employers. One problem with this approach is whether there is a source of authority for such a suit by the trustee on behalf of bankrupt's creditors. See Landers, A Unified Approach to Parent, Subsidiary, and Affliate Questions in Bankruptcy, 42 U. CHr. L. Rev. 589, 607-16 (1975). In any event, such a suit by the trustee would constitute a part of the administration of Local 600's bankrupt estate-that is it would necessarily take place subsequent to the local union's adjudication as a bankrupt and probably would also take place subsequent to issuance of an order discharging Local 600 on the section 301 judgment debt. 
why Judge Brauer isolated the employers' original failure to join the international in the section 301 action as a significant ground for holding Local 600 an appropriate bankruptcy person. ${ }^{73}$

Identification of status as a bona fide union should be sufficient to èstablish a local union as an appropriate bankruptcy person. This simple identification requirement is preferable to the functional autonomy test for two reasons. First, it is easier to administer and more predictable. All that is necessary is a positive identification of the union. ${ }^{74}$ This is to be contrasted with the potentially extensive hearing that might be necessary under the functional autonomy test to ascertain the local's independence from international control. ${ }^{75}$

Second, a simple identification requirement implements the relevant bankruptcy policy without introducing the extraneous issue of an international's liability on a local's debts. The conclusion reached in section II that bankruptcy coverage should extend to unions involved a determination as a matter of bankruptcy policy that a union is entitled to discharge subject to the equitable distribution of its existing assets among its creditors. ${ }^{76}$ Whether an entity that establishes its status as a bona fide union is controlled by another entity is irrelevant in terms of this policy determination. The latter entity will not be afforded discharge and its existing assets will still be available to satisfy liability to creditors. There is no reason, therefore, why a bankruptcy court should not defer to legal form and recognize a local union as a person separate from its international for purposes of being adjudicated bankrupt. Indeed, in the analogous situation of parent and subsidiary corporations, bankruptcy courts have deferred to the formal legal separateness of subsidiaries and recognized them as appropriate bankruptcy persons without inquiring into their substantive autonomy vis-à-vis their parents. ${ }^{77}$

73 See note 69 supra \& accompanying text.

74 Evidence such as National Labor Relations Board certification, see 29 U.S.C. $\$ 159$ (c)(1) (1970), would be probative on the identification issue.

75 Obviously, identification of the union would also be necessary under the functional autonomy approach. All this Comment proposes is that a bankruptcy court stop after it is satisfied as to the presence before it of a bona fide union and that it not hear evidence regarding local independence or lack thereof.

76 See notes 52-58 supra \& accompanying text.

77 This proposition can be deduced on the basis of those cases that deal with actions brought by the creditors and trustees, see note 72 supra, of bankrupt subsidiaries against the parent corporations on a primary liability theory. See Fish v. East, 114 F.2d 177 (10th Cir. 1940); Henderson v. Rounds \& Porter Lumber Co., 99 F. Supp. 376 (W.D. Ark. 1951) (parent held liable). See generally Landers, supra note 72, at 606-28. Necessarily the subsidiaries were adjudicated bankrupt 


\section{Conclusion}

In re Highway \& City Freight Drivers Local 600 is another in a growing collection of cases ${ }^{78}$ that raise issues of alleged conflicts between provisions and policies of federal bankruptcy and labor law. The district and bankruptcy courts adopted two very different attitudes towards the judicial role in reconciling these two bodies of federal law. The district court essentially "remanded to Congress" to break its legislative silence regarding bankruptcy coverage of labor organizations. ${ }^{79}$ The bankruptcy court adopted the better approach. Express legislative intent to include or exclude labor organizations being absent, the latter court set about reaching a conclusion responsive to both federal policies. ${ }^{80}$

prior to the creditors and trustees bringing these actions against the parents. Had the functional autonomy approach been taken by the bankruptcy court with regard to the subsidiary of the parent ultimately held vicariously liable in Henderson, then presumably the subsidiary would never have been adjudicated bankrupt.

A different issue may be presented when it is the international union which is seeking voluntary bankruptcy. The creditors of the international will presumably not have a vicarious liability claim against the local(s). Rather the allegation to the bankruptcy court will be that given the international's "control" of the local, the local's assets form a part of the international's bankrupt estate subject to distribution to the international's creditors. In such a case consolidation of the international and local might be imposed as a precondition to adjudicating the international bankrupt because it would be contrary to bankruptcy policy to release future assets of the international from the claims of creditors unless all existing assets under the dominion of the international are brought under the bankruptcy court's jurisdiction for purposes of equitable distribution among creditors. $C f$. Landers, supra note 72, at 628-51 (treatment of the analogous problem of consolidation of parent and subsidiary corporations when the parent is bankrupt). But see Posner, The Rights of Creditors of Affliated Corporations, 43 U. CEr. L. Rev. 499 (1976).

78 See note 62 supra.

79 Judge Wangelin expressed his view as follows:

A final word on federal labor policy [insofar as it affects the coverage of the Bankruptcy Act] is necessary. The essence of labor law is the balance of power between labor and management. That balance may only be disturbed by Congress. . . . Although the constitutional parameters of the bankruptcy power may be defined by the courts, its exercise is vested in the legislative branch. ... The judicial inclusion of labor organizations in section 4 of the Bankruptcy Act would usurp that legislative power.

432 F. Supp. at 1330 (citations omitted).

80 Judge Brauer observed:

[I]f the availability of bankruptcy to a labor organization were shown to create strife and unrest and discord land thus present an irreconcilable conflict with federal labor policy], Congress can easily and quickly exclude, by specific provision in the [Bankruptcy] Act, the availability of bankruptcy to a labor organization, as it has already done to various entities by Section 4 of the Act.

No. 76-1517B, slip op. at 11-12. 
A close analysis of statutory construction, legislative history, and federal policy argue for extending bankruptcy coverage to labor unions. Indeed, no solid justification exists for denying a local union's voluntary petition in bankruptcy whether or not it is joined by its international organization. 